\title{
特集 「女性の医学」
}

\author{
更年期障害 \\ 前 林 亜 紀 \\ 日本大学病院産婦人科

\section{Climacteric Disorder} \\ Aki MaEBAYASHI \\ Department of Obstetrics and Gynecology, Nihon University Hospital
}

\begin{abstract}
Menopausal symptoms are defined as symptoms that are not caused by organic changes among a wide variety of symptoms that appear during menopause. When these symptoms interfere with daily life, the pathological condition is defined as menopausal disorder. Ovarian dysfunction is a major factor in the pathogenesis of menopause, but sociopsychological stress, which is a family and workplace problem women experience during this period, is also an important factor. Personality factors are also intricately intertwined and show various symptoms. The diagnosis is that the patient is menopausal and has the peculiar symptoms mentioned. If organic disease is denied, the condition is considered to be menopausal disorder, but there are no international standard diagnostic criteria. Comprehensive evaluation of women with menopausal disorder shows ovarian function decline, age-related physical changes, psychological and psychological factors, and sociocultural environmental factors. Hormone therapy, the use of psychotropic drugs, and other treatments are effective. In Japan, kampo drug treatment for menopausal symptoms has been adopted for a long time. Furthermore, counseling and psychotherapy are also effective.
\end{abstract}

Key words: menopause, climacteric period, climacteric disorder, STRAW +10 , hormone replacement therapy 閉経，更年期，更年期障害，STRAW+10，ホルモン補充療法

(J. Nihon Univ. Med. Ass., 2021; 80 (4): 177-180)

\section{はじめに}

日本では，閉経前 5 年，閉経後 5 年を合わせた 10 年 間を更年期としている。性成熟期から老年期への移行を 指す用語として本邦では定着しているが，国際的には使 用頻度は高くない．閉経は卵巣の活動が次第に低下し， 月経が永久に停止し，12 力月以上の無月経を確認し判断 される. 日本人の閉経年齢の中央值は 52 歳であった ${ }^{1)}$. 更年期症状は, 「更年期に現れる多種多様な症状の中 で, 器質的変化に起因しない症状」と定義され, その症 状の中で日常生活に支障をきたす病態を更年期障害とし ている ${ }^{2)}$ 。実際には自律神経失調症状と精神症状が相互 に修飾しあい病像を複雑にしていることが多い.

近年, 国際的には更年期 (climacterium) という用語は 使われなくなってきており，WHOはStages of Reproductive Aging Workshopによる分類を提唱している7) (Table 1). そこでは，女性における生殖に関する加齢を 10 のステージに分類しそれぞれの月経状況やホルモン 変化が規定されている．更年期すなわち閉経期への移行 は，生殖老化にともなう生理的変化である，生理的変化 は, 一時的な変化 (血管運動症状, 睡眠障害, 精神症 状）と長期的な変化（泌尿生殖症状, 骨・代謝の変化） に分けられる。ここでは一時的変化，いわゆる更年期障 害について概説する.

\section{更年期障害の概要}

女性は, STRAW+10に示されているような, 生殖老化 のステップを順にすすんでゆく．周閉経期では，ステー ジをスキップしたり，ステージ間を行ったり来たりする など，個人差がかなりある．更年期障害の成因としては， 上述の内分泌的, 加齢, 社会環境的, 心理的要因が関連 し合い生じると考えられている。更年期で重要となる生 物学的変化は, 卵巣機能の低下, 消退である。 女性の体 の多くの臓器, 組織にエストロゲン受容体が存在してい ることが明らかになっており, 更年期にはこれらの藏器 にさまざまな障害をきたすとされる。更年期障害の症状 は, Table 2 のように多岐にわたる. 内分泌的変化に加 え, Table 3 のような社会心理的ストレスも同時に経験 する背景が, 病像を複雑化している ${ }^{4)}$. 更年期障害に対 する治療は，習慣にもとづくものが多く，時には深刻な 症状が治療されず，逆に軽度な症状が過度に治療された りすることがあった。 症状の成因をみきわめ, 個々に対 応することが大切である。

\section{更年期障害の症状}

\section{I . 自律神経失調症状 \\ 血管運動神経症状}

通常，胸，首，顔に感じられる自発的なあたたかさの 
Table 1 Modifid from STRAW+10.

\begin{tabular}{|c|c|c|c|c|c|}
\hline Stage & -2 & -1 & $+1 a$ & $+1 b$ & $+1 c$ \\
\hline \multirow[t]{2}{*}{ Terminology } & $\begin{array}{l}\text { Menopausal } \\
\text { Transition }\end{array}$ & $\begin{array}{l}\text { Menopausal } \\
\text { Transition }\end{array}$ & $\begin{array}{l}\text { Post } \\
\text { menopaus } \\
\text { e }\end{array}$ & $\begin{array}{l}\text { Post } \\
\text { menopaus } \\
\text { e }\end{array}$ & $\begin{array}{l}\text { Post } \\
\text { menopause }\end{array}$ \\
\hline & Early & Late & Early & Early & Early \\
\hline Duration & variable & $1-3$ years & 2 years & 2 years & 3- 6 years \\
\hline \multicolumn{6}{|l|}{ Principal Criteria } \\
\hline Menstrual Cycle & $\begin{array}{l}\text { Variable } \\
\text { length } \\
\text { persistent } \\
\geqq 7 \text { day } \\
\text { difference in } \\
\text { length of } \\
\text { consecutive } \\
\text { cycles }\end{array}$ & $\begin{array}{l}\text { Interval of } \\
\text { amenorrhea } \\
>=60 \text { days }\end{array}$ & & & \\
\hline \multicolumn{6}{|l|}{ Supportive Criteria } \\
\hline $\begin{array}{l}\text { FSH } \\
\text { AMH } \\
\text { Inhibin B }\end{array}$ & $\begin{array}{l}\uparrow \text { Variable } \\
\text { Low } \\
\text { Low }\end{array}$ & $\begin{array}{l}\uparrow>25 \\
I U / L \\
\text { Low } \\
\text { Low }\end{array}$ & $\begin{array}{l}\uparrow \text { Variable } \\
\text { Low } \\
\text { Low }\end{array}$ & $\begin{array}{l}\uparrow \text { Variable } \\
\text { Low } \\
\text { Low }\end{array}$ & $\begin{array}{l}\text { Stabilizes } \\
\text { Very Low } \\
\text { Very Low }\end{array}$ \\
\hline Antral Follicle count & Low & Low & Very Low & Very Low & Very Low \\
\hline \multicolumn{6}{|l|}{$\begin{array}{l}\text { Descriptive } \\
\text { Characteristics }\end{array}$} \\
\hline Symptoms & & $\begin{array}{l}\text { Vasomotor } \\
\text { symptoms } \\
\text { Likely }\end{array}$ & $\begin{array}{l}\text { Vasomotor } \\
\text { symptoms } \\
\text { Most } \\
\text { Likely }\end{array}$ & $\begin{array}{l}\text { Vasomotor } \\
\text { symptoms } \\
\text { Most } \\
\text { Likely }\end{array}$ & \\
\hline
\end{tabular}

Table 2 Symptoms of menopause.

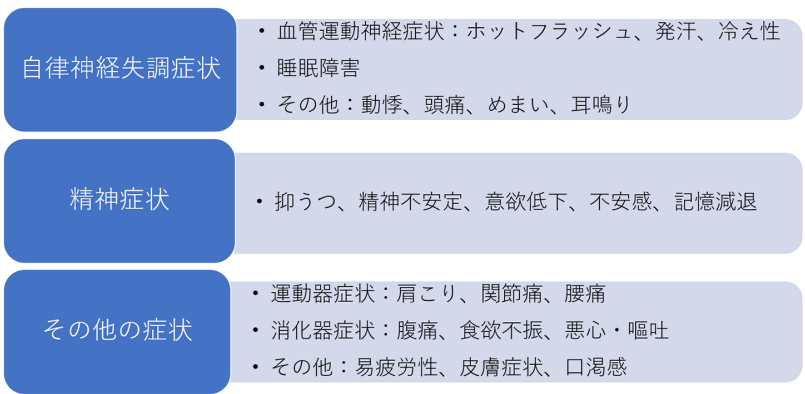

感覚とされ,「ほてり」「のぼせ「「ットフラッシュ」 と呼ばれる ${ }^{5)}$. 平均的なホットフラッシュは約 4 分続く が，数秒から約 10 分続くこともある。暖かな環境，食 べ物や飲み物，ストレスによって出現する。更年期の女 性の約 $2 / 3$ がホットフラッシュを経験している。運動習 慣がない女性，喫煙者で有病率が高くなる。アジア人は 白人女性よりも血管運動症状を訴えることが少なく, 若 い年齢で更年期になった女性は症状がより重症化しやす $\left(^{6}\right.$ ．一般的には一年以内には治まるとされる7)。ほて りの原因は視床下部中枢神経系にある。体温調整は，七 ロトニンとノルエピネフリンが関与しているとされる。 通常エストロゲンは，中枢神経系を介し体温調整のセッ トポイントを安定化させている，閉経によるエストロゲ ンの低下で，セロトニン量が減少し，これによりセット
Table 3 Social psychological stress surrounding menopausal women.

\begin{tabular}{|c|c|c|}
\hline 家族の問題 & 職場の問題 & 自分自身の問題 \\
\hline $\begin{array}{l}\text { - 配偶者の病気や } \\
\text { 死、定年、不和 } \\
\text { - 子供の受験、自 } \\
\text { 立 } \\
\text { - 親の介護や死 }\end{array}$ & $\begin{array}{l}\text { • 人間関係 } \\
\text { • 責任の増大 }\end{array}$ & $\begin{array}{l}\text { ・健康に対する自 } \\
\text { 信の㙅失、老化 } \\
\text { の意識 } \\
\text { ・空の宩症候群 }\end{array}$ \\
\hline
\end{tabular}

ポイントの閾值が下がり，わずかな体温上昇や外的刺激 に対して反応してホットフラシュが起こるとされる6,7). 日本人女性に扔ける研究では, BMI の増加は, ほてり や発汗などの血管運動症状の重症度と関連している結果 を示した ${ }^{8)}$ 。ホルモン補充療法のよい適応で，大規模な ランダム試験の結果，ホルモン補充療法はホットフラッ シュを $50 \%-100 \%$ 減少させたと報告がある6).

睡眠障害，頭痛，めまい

日本人の周閉経期から閉経後の女性では，不眠症の有 病率が 50 \%を超える。不眠症は血管運動症状よりも抑 うつ障害とより相関し，不眠症の女性の $30 \%$ は抑うつ 状態であったとされる9). 頭痛は緊張型頭痛, 片頭痛, 自律神経頭痛に分類される。経や周閉経期のホルモン の変動が関与し，閉経後は軽減することが多い，周閉経 
期の日本人女性で，めまいの有病率は $35 \%$ であり，多 くの更年期症状の中でも，不安症状との相関がある.

\section{II. 精神症状}

更年期障害の精神症状には，抑うつ，精神不安定，意 欲低下，不安感，記憶減退などがある。これらの原因と して，身体因子の他にも外的因子，すなわち社会心理的 ストレスも関与する.

更年期は，思春期や月経前，産裖期などと同様に，ホ ルモン変化に特に敏感な時期といわれる ${ }^{10)}$. 女性の生涯 にわたるホルモンの変動は, 気分障害発症の危険因子と なっている。エストロゲン, プロゲステロンなどのホル モンは，主要な神経伝達物質である，七ロトニン，ドー パミン，GABA，グルタメートなどを調整しており，そ の変化が気分障害を抗こしていると考えられている。更 年期は，中枢神経系の脆弱性が高まる期間であり，早期 に閉経した女性ではうつ病発症のリスクが高く，うつ病 の既往がある女性もこの期間の再発リスクが高くなる ${ }^{11)}$. また卵巣ホルモンは, 学習, 記憶, 感情, 認知機能の活 動性を高める役割をしている。この働きが低下する更年 期では，抑うつ，不安，意欲低下，記憶減退が生じるが と考えられる。

\section{III. その他の症状}

腟の乾燥，かゆみ，性交時痛などの生殖器の問題は, ホルモン低下により腟の血流と分泌物が減少し, 腟内環 境が酸性から中性へと変化することに起因する5 肩こり，関節痛，腰痛，易疲労性など，更年期に現れる 症状は多彩だが，これらは周閉経期との関連はそしいと される，日本人女性では，全身倦总感や肩こりが他の症 状よりも頻度が高い特徴がある ${ }^{12)}$ 。 ホルモン補充療法で 改善が見られる場合もあるが，他疾患の検索も必要であ る.

\section{更年期障害の診断}

患者が更年期であり，前項で挙げた特有な症状を有 し, 器質的疾患が否定されれば更年期障害と考えられる が，国際的にも標準的な診断基準は存在しない.

卵巣機能の低下，加齢に伴う身体的変化，精神 · 心 理的な要因, 社会文化的な環境因子を包括的に評価す $ろ^{13)}$ 。症状の認識として，Kuppermann 更年期指数，簡 易更年期指数 simplified menopausal index; SMI などが使 用されることがある. Stages of Reproductive Aging Workshop も更年期の状況を把握するため参考になる。

\section{更年期障害の治療}

\section{I．薬物療法}

(1)ホルモン補充療法 (hormone replacement therapy: HRT) エストロゲン製剤を投与する治療の総称でる。エスト ロゲン低下の影響を受けている症状，すなわち血管運動
神経症状，性器萎縮症状がよい適応となる ${ }^{13)}$ 。また，視 床-下垂体-卵巣系の機能的変化が著しい，周閉経期女性 のうつ症状に対する HRT は有効であるが，卵巣機能が 完全に減衰した女性に対しては無効とされる ${ }^{10,13)}$ 。他の 利点として, 骨粗鬆症の予防, HDL コレステロールの 増加と LDL コレステロール濃度の低下, 泌尿生殖器の 萎縮に関連する症状に有効である ${ }^{6)}$ ．エストロゲンの副 反応は, 子宮出血, 乳房痛, 悪心嘔吐, 頭痛, 体重変化, 肝障害などがある。また，HRTにより増加する可能性 のある疾患として, 冠動脈疾患, 脳卒中, 静脈血栓塞栓 症，乳がん，卵巣がんが挙げられる。心血管疾患，血栓 症，乳がんまたは子宮体がん，またはその既往，原因不 明の不正性器出血，妊娠が疑われる場合，肝疾患のある 女性には使用禁忌である5,13)。

\section{(2)向精神薬}

選択的セロトニン再取り込み阻害薬 (SSRI) やノルア ドレナリン再取り込み阻害薬 (SNRI) が用いられる。抑 うつ傾向があるもの，心理的背景をもつものに用いられ るが，体温調節に関わるセロトニンも調整することから， ホットフラッシュの頻度や強さの改善にも効果がある ${ }^{5,7)}$. 副反応として，嘔気，便秘，食欲不振，体重減少などが 10-20\%で起こる。 その他にも, 倦㤐感, 興奮, 頭痛, 振戦などがある゙).

\section{(3漢方療法}

日本では従来から漢方療法がよく使われており，当帰 药薬散, 桂枝获苓丸, 加味逍遙散は三大漢方婦人薬と呼 ばれる。更年期症状の適応をもつ漢方は他にも多く,

「証」により使い分ける.

当帰药薬散：体力が中等度以下で瘀血（血の流れが悪 くなり，滞っている状態）と水毒（水分が過㮃になり貯 留した状態）に対する処方であり，手足の冷え，下腿浮 腫やめまいなどに処方する.

加味逍遙散 : 体力が中等度以下で動悸・発汗・ホット フラッシュなどの血管運動神経症状，精神不安やいら立 ち，様々な不定愁訴に処方する。

桂枝茯苓丸：体力が中等度かそれ以上で，瘀血の諸症 状があり，のぼせて赤ら顔，下腹部に抵抗や圧痛がある 人に処方する ${ }^{14)}$.

\section{(4)補完代替医療}

代表的なものは，植物エストロゲンの大豆エストロゲ ンで，ホットフラッシュを減少させることが知られてい る. 高用量 - 長期間の投与により子宮内膜増殖症の増加 を示したことから，食品からの摂取で安全に上乗せでき る摂取量をアグリコン (非配糖体) 型換算で $30 \mathrm{mg} /$ 日 までとしている。また，HRTを施行できない乳がんサ バイバーへの有効性も期待される ${ }^{13)}$. 


\section{II . カウンセリング・心理療法}

更年期障害の発症には, 社会心理ストレス (Table 3) を背景とすることも多い. 本格的なカウンセリングでな くとも，診察では常に，相談者自身の感じ方に焦点を当 て肯定的関心を持つ「受容」と，相談者を共感的に理解 しょうと努め，それを相手に伝える「共感的理解」の姿 勢が必要とされる。また, 認知行動療法は, 不安や抑う つだけでなく, 不眠やホットフラッシュ, 寝汗への効果 もあるとされる ${ }^{15)}$.

\section{おわりに}

更年期障害の発生機序としては，卵巣機能低下が大き な要素であるが，この時期に女性を取り巻く，家族，職 場の問題からなる社会心理的ストレスも重要な因子であ る。性格的要因も複雑に絡み合い, 多彩な症状を示す. 治療も状況に合わせ組み合わせて進めていく。この時, 患者に対する共感的姿勢が重要である。ささらに生活習慣 の改善，ストレスの軽減など，七ルフケアでできるアプ ローチを一緒に考えることも大切である.

利益相反はありません。

\section{文献}

1) Yasui $T$, Hayashi $K$, Mizunuma H, et al. Factors associated with premature ovarian failure, early menopause and earlier onset of menopause in Japanese women. Maturitas 2012; 72: 249-255.

2) 日本産科婦人科学会編: 産科婦人科用語集-用語解説集. 2018. 金原出版, 東京.

3) Harlow SD, Gass M, Hall JE, et al. Executive summary of the Stages of Reproductive Aging Workshop + 10: addressing the unfinished agenda of staging reproductive aging. Fertil Steril 2012; 97: 843-851.

4）武谷雄二, 上妻志郎, 藤井智之, 他. 中高年女性の好発 疾患と健康管理。プリンシプル産婦人科. Medical View, 東京, 2014; 616-623.

5) Nelson HD. Menopause. Lancet 2008; 371: 760-770.

6) Stearns V, Ullmer L, López JF, et al. Hot flushes. Lancet 2002; 360: 1851-1861.

7) Rapkin AJ. Vasomotor symptoms in menopause: physiologic condition and central nervous system approaches to treatment. ALOG 2007; 196: 97-106.

8) Yokota M, Makita K, Hirasawa A, et al. Symptoms and effects of physical factors in Japanese middle-aged women. Menopause 2016; 23: 974-983.

9) Terauchi M, Obayashi S, Akiyoshi M, et al. Insomia in Japanese peri- and postmenopausal women. Climacteric 2010; 13: 479-486.

10) Pauline MM, Kornstein SG, Joffe H, et al. Guidelines for the Evaluation and Treatment of Perimenopausal Depression: Summary and Recommendations. J Womens Health 2019; 28: 117-134.

11) Barth C, Villringer A, Sacher J. Sex hormones affect neurotransmitters and shape the adult female brain during hormonal transition periods. Front Neurosci 2015; 9: 1-20.

12) Kasuga M, Makita K, IShitani K, et al. Relation between climacteric symptoms and ovarian hypofunction in middle-aged and older Japanese women. Menopause 2004; 11: 631-638.

13）日本産婦人科学会 日本産婦人科医会. 産婦人科診療ガ イドライン 婦人科外来編 2020. 日本産科婦人科学会事 務局.

14）貝沼茂三郎．漢方の使い方，産婦人科の実際 2019； 68: $517-521$.

15) Hunter M, Smith M. In Collaboration With The British Menopause Society. Cognitive Behaviour Therapy (CBT) for menopausal symptoms: Information for GPs and health professionals. Post Reprod Health 2017; 23: 83-84. 